\title{
Antibodies from Multiple Sclerosis Brain Identified Epstein-Barr Virus Nuclear Antigen 1 \& 2 Epitopes which Are Recognized by Oligoclonal Bands
}

\author{
Zhe Wang $^{1} \cdot$ Peter GE Kennedy ${ }^{2} \cdot$ Cecily Dupree $^{3} \cdot$ Min Wang $^{4} \cdot$ Catherin Lee $^{3} \cdot$ Tiffany Pointon $^{3}$.

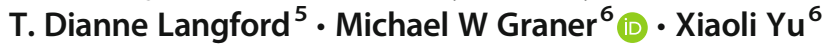

Received: 11 May 2020 / Accepted: 27 July 2020 / Published online: 18 August 2020

(C) Springer Science+Business Media, LLC, part of Springer Nature 2020

\begin{abstract}
Multiple sclerosis (MS) is a chronic inflammatory demyelinating disease of the central nervous system (CNS), the etiology of which is poorly understood. The most common laboratory abnormality associated with MS is increased intrathecal immunoglobulin $\mathrm{G}(\mathrm{IgG})$ synthesis and the presence of oligoclonal bands (OCBs) in the brain and cerebrospinal fluid (CSF). However, the major antigenic targets of these antibody responses are unknown. The risk of MS is increased after infectious mononucleosis (IM) due to EBV infection, and MS patients have higher serum titers of anti-EBV antibodies than control populations. Our goal was to identify disease-relevant epitopes of IgG antibodies in MS; to do so, we screened phage-displayed random peptide libraries (12-mer) with total IgG antibodies purified from the brain of a patient with acute MS. We identified and characterized the phage peptides for binding specificity to intrathecal IgG from patients with MS and from controls by ELISA, phage-mediated Immuno-PCR, and isoelectric focusing. We identified two phage peptides that share sequence homologies with EBV nuclear antigens 1 and 2 (EBNA1 and EBNA2), respectively. The specificity of the EBV epitopes found by panning with MS brain IgG was confirmed by ELISA and competitive inhibition assays. Using a highly sensitive phage-mediated immuno-PCR assay, we determined specific bindings of the two EBV epitopes to IgG from CSF from $46 \mathrm{MS}$ and 5 inflammatory control (IC) patients. MS CSF IgG have significantly higher bindings to EBNA1 epitope than to EBNA2 epitope, whereas EBNA1 and EBNA2 did not significantly differ in binding to IC CSF IgG. Further, the EBNA1 epitope was recognized by OCBs from multiple MS CSF as shown in blotting assays with samples separated by isoelectric focusing. The EBNA1 epitope is reactive to MS intrathecal antibodies corresponding to oligoclonal bands. This reinforces the potential role of EBV in the etiology of MS.
\end{abstract}

Keywords Multiple sclerosis · IgG antibodies · Oligoclonal bands · Epstein-Barr virus (EBV) · EBNA · CNS · Phage display · Peptides $\cdot$ Epitope

Michael W Graner and Xiaoli Yu contributed equally to this work.

Electronic supplementary material The online version of this article (https://doi.org/10.1007/s11481-020-09948-1) contains supplementary material, which is available to authorized users.

Michael W Graner

michael.graner@cuanschutz.edu

Xiaoli Yu

xiaoli.yu@cuanschutz.edu

1 National Engineering Research Center for Protein Drugs, Beijing 102206, China

2 Institute of Infection, Immunity and Inflammation, University of Glasgow, Glasgow, UK
3 Department of Neurology, University of Colorado Anschutz Medical Campus, Aurora, CO, USA

4 Immunoah Therapeutics, Inc., 12635 East Montview Boulevard, Aurora, CO 80045, USA

5 Lewis Katz School of Medicine, Temple University, 3500 N. Broad St, Philadelphia, PA 19140, USA

6 Department of Neurosurgery, University of Colorado Anschutz Medical Campus, Aurora, CO, USA 


\section{Introduction}

Multiple sclerosis (MS) is a chronic inflammatory disease of the central nervous system (CNS) characterized by demyelination and gliosis, with various degrees of axonal pathology and episodic or progressive neurological disability (Compston and Coles, 2008). A persistent synthesis of IgG antibodies (manifested as oligoclonal bands) in the cerebrospinal fluid (CSF) and brain is an immunological hallmark usually seen in MS (Compston and Coles, 2008). However, the major antigenic target(s) of this increased $\mathrm{IgG}$ is unknown (Graner et al., 2020). We have shown recently that in MS, there is a complex relationship between oligoclonal bands, and immunoglobulin $\mathrm{G}$ antibodies (Beseler et al., 2017). In MS patients, longitudinal analyses of serum samples collected more than 10 years before the onset of clinical symptoms consistently showed that the risk of developing the disease increased significantly with the level of EBV antibody titers, with the strongest association being found for IgG antibodies binding to an EBV latent antigen, nuclear antigen 1 (EBNA1) (Ascherio et al., 2001; Levin et al., 2005; DeLorenze et al., 2006). EBNA1, the crucial EBV antigen for latency of the virus, constitutes a dominant antigen for both humoral and cell-mediated immune responses to the virus, and the deregulation of EBV-specific immunity in MS has been reported primarily for this antigen (Lunemann et al., 2007).

Several lines of epidemiological and seroepidemiological evidence also support the notion of EBV infection playing a potential role in MS. For example, there is an increased risk of developing MS among individuals with a history of infectious mononucleosis (Thacker et al., 2006); there are some similarities in the epidemiology of MS and infectious mononucleosis (Warner and Carp, 1981); there is an almost universal seropositivity for EBV in adults and children with MS (Ascherio et al., 2001; Alotaibi et al., 2004); there is a steep and monotonic increase in MS risk with increasing titers of antibodies to EBV in apparently healthy adults (Sundstrom et al., 2004; Levin et al., 2005); and elevated EBNA1 immune responses predict the conversion to MS (Lunemann et al., 2007).

An increased frequency of IgG reactivity to EBNA1 was found in MS patients using a cDNA protein-expression array containing 37,000 tagged proteins (Cepok et al., 2005). The findings of this study are in accordance with previous reports on a higher frequency of CSF-derived EBNA1-specific IgG antibodies in patients with MS (Bray et al., 1992). Using CSF IgG from MS patients and from controls to select peptides from a filamentous phage display library, five out of $14 \mathrm{MS}$ patients and one out of 14 controls had distinctive reactivity for a 6 amino acid motif found in EBNA1 (Rand et al., 2000). These data suggest that EBVspecific antibodies not only are systemically elevated in MS but also are enriched in the CSF of affected patients.
Phage-displayed random peptide libraries provide an extremely powerful technique for the selection of ligands binding to antibodies. This technology has been used successfully to identify antigens/epitopes of disease-specific antibodies directed at either infectious agents (Ferrer and Harrison, 1999; Heiskanen et al., 1999; Owens et al., 2006), auto-antigens (Rudolf et al., 1998; Zhang and Davidson, 1999) or recombinant antibodies from MS (Yu et al., 2011b). Herein we report the identification and characterization of two EBV nuclear antigen epitopes (EBNA1 and EBNA2). These were identified by screening a phage-displayed random peptide library with IgG antibodies purified from an acute MS brain, with further analyses of the peptide binding profiles to $\operatorname{IgG}$ antibodies in 46 MS CSF and 5 CSF obtained from inflammatory controls (IC) using a highly sensitive phage mediated immuno-PCR assay.

\section{Methods}

\section{MS IgG and CSF}

MS brain IgG antibodies (MS 95-2) used for panning random peptide libraries were purified from a postmortem brain plaque-periplaque white matter of an acute MS patient (Owens et al., 1997). MS and IC CSF samples were collected with approval from the University of Colorado Institutional Review Board (COMIRB \# 00-688) (Beseler et al., 2017). One MS patient was of secondary-progressive type (SPMS), and all other MS patients were of the relapsing-remitting type (RRMS). The inflammatory central nervous system disease (IC) controls included subacute sclerosing panencephalitis (2), Behcet's disease (1), viral meningitis (1), and cryptococcal meningitis (1).

\section{Biopanning}

The PhD-12 ${ }^{\text {TM }}$ Phage Display Peptide Library (New England BioLabs, Beverly, MA) was used for affinity selection of specific peptides by MS brain IgG antibodies. Detailed procedures for panning, phage amplification and DNA sequencing were carried out as previously described ( $\mathrm{Yu}$ et al., 2006b). Among the phage clones sequenced, phage/phage peptides 3 2 and 3-3 were used in the rest of the analyses.

\section{Sequence Analyses}

Single-stranded phage DNA was sequenced, the deduced amino acid sequences were obtained, and the peptide sequences identified. The UniProKB/Swiss-Prot (swissprot) database was used to search for target virus proteins (https://blast. ncbi.nlm.nih.gov/Blast.cgi?LINK_LOC=blasthome\&PAGE TYPE=BlastSearch\&PROGRAM=blastp). The consensus 
peptide sequences in the EBV virome were identified by sequence alignment using ClustalW (https://npsa-prabi.ibcp. fr/cgi-bin/npsa_automat.pl?page=npsa_clustalw.html) with the following options used: endgaps $=1$; gapdist $=8$; gapext $=0.2 ;$ gapopen $=10.0 ;$ hgapresidues $=$ GPSNDQERK; matrix = gonnet; maxdiv $=30$; outorder $=$ input; pwgapext $=0.1$; pwgapopen $=10.0 ;$ pwmatrix $=$ gonnet; type = PROTEIN. EBV sequences used for EBNA1 were UniProt P03211 (Epstein-Barr nuclear antigen 1, Epstein-Barr virus (strain B95-8) (HHV-4) (Human herpesvirus 4)), and for EBNA2 were UniProt P12978 (Epstein-Barr nuclear antigen 2, Epstein-Barr virus (strain B95-8) (HHV-4) (Human herpesvirus 4). Alignments were performed against the entire EBV virome/proteome (both reviewed/annotated and hypothetical) from these sources:

http://www.virosnet.cs.huji.ac.il/viralproteins/ showproteins.php?var=10376\&a=Human + herpesvirus + $4 \& \mathrm{key}=$

https:/www.viprbrc.org/brc/home.spg?decorator=herpes

Peptide sequence abundance was calculated based on the number of identical clones from the total phage clones sequenced.

\section{Peptide Antigenicity/Epitope Characterization}

Putative B cell antigens/epitopes were predicted for phage peptides 3-3 and 3-2, as well as for the stretches of peptide sequence from the parental EBNA1 and EBNA2 proteins that were identified in the ClustalW predictions. We used the following programs, algorithms and servers for this:

\begin{abstract}
"Peptide Antigen Prediction", Universidad Complutense Madrid Immunomedicine Group Tools (http://imed.med. ucm.es/Tools/antigenic.pl) From (Kolaskar and Tongaonkar, 1990), predictions are based on the occurrence of amino acid residues in experimentally known segmental epitopes. The average antigenic propensity for each overlapping 8-mer is determined and compared to the average for the whole protein. If the average for the whole protein is above 1.0 , then all residues having scores above 1.0 are potentially antigenic. If the average for the whole protein is below 1.0, then all residues having scores above the average for the whole protein are potentially antigenic.
\end{abstract}

\section{SVMTriP}

(http://sysbio.unl.edu/SVMTriP) This assesses potential linear B cell epitopes using Support Vector Machine learning which integrates tri-peptide similarity and propensity scores (SVMTriP) (Yao et al., 2012).

\section{BcePred Prediction Server}

(http://crdd.osdd.net/raghava/bcepred/) The BcePred server predicts B cell epitopes of peptides using physicochemical properties (hydrophilicity, flexibility/mobility, accessibility, polarity, exposed surface and turns) or their combinations and puts them in the context of an antigen propensity score. Graphically, the server plots amino acid residue properties along the protein backbone. The peak of the amino acid residue segment above the threshold value is considered a predicted B cell epitope. The table output gives the normalized score of the selected properties with the corresponding amino acid residue of a protein along with the maximum, minimum and averages values of the combined methods selected. Threshold values are as follows: hydrophilicity $=1.9$; flexibility $=2.0$; accessibility $=$ 1.9 ; turns $=2.4$; expose surface $=2.3$; polarity $=1.8$; antigenic propensity $=1.9$.

\section{ABCpred Prediction Server}

(https://webs.iiitd.edu.in/raghava/abcpred/index.html) The ABCpred server uses a form of artificial neural networking. In this case it is a partial recurrent neural network with a single hidden layer of 35 residues, and an optional network window length of 10 . The output consists of a single binary number of 1 or 0 (epitope or non-epitope). The predicted B cell epitopes are ranked according to their score obtained by trained recurrent neural networks; a higher score for a peptide indicates a higher probability as an epitope. Peptides shown are above the threshold value chosen ( 0.51 in these cases) (Saha and Raghava, 2006).

\section{BepiPred-2.0: Sequential B- Cell Epitope Predictor}

(http://www.cbs.dtu.dk/services/BepiPred/) To predict B cell epitopes from a protein sequence, the BepiPred-2.0 server uses a Random Forest algorithm trained on epitopes and non-epitope amino acids determined from crystal structures, followed by a sequential prediction smoothing. Sequences colored in the orange gradient are predicted to be above the threshold (here set at 0.51) (Jespersen et al., 2017).

\section{Peptide Structure Predictions}

Structures for Pep 3-3, Pep 3-2, and their corresponding homologous sequences in EBNA1 and EBNA2 (EBNA1 $386-416$ and EBNA2 263-286) were rendered using PepFold 3.5 (http:// bioserv.rpbs.univ-paris-diderot.fr/services/PEP-FOLD3/) (Lamiable et al., 2016). 


\section{ELISA}

Purified MS brain 95-2 IgG in $0.1 \mathrm{M}$ carbonate buffer $(50 \mu \mathrm{l}$, $200 \mu \mathrm{g} / \mathrm{ml}$ ) was coated onto wells of ELISA plates overnight at $4{ }^{\circ} \mathrm{C}$. The wells were then blocked with $3 \%$ BSA for $2 \mathrm{~h}$ followed by incubation with purified phage $3-2$ and $3-3$ ( $5 \times$ $10^{9} /$ well) for $1 \mathrm{~h}$. After washing with $0.05 \%$ Tween-20/Tris buffered saline (TBST), the wells were incubated with a 1:500 dilution of mouse anti-M13 IgG-HRP (New England BioLabs) antibody for $1 \mathrm{~h}$, followed by incubation with peroxidase substrate ABTS (Vector Laboratories, Burlingame, CA) for $20 \mathrm{~min}$. The optical absorbance was measured at $415 \mathrm{~nm}$ with a Microplate Manager (BioRad, Hercules, CA). All samples were tested in duplicate and the ELISA was repeated at least one additional time.

Phage Mediated Immuno-PCR for Phage Binding Specificity Wells of protein A coated plates were added with panning MS antibodies (5-fold serial dilutions) and incubated with equal amount of phage 3-3 and 3-2 (10\%/well) respectively. Bound phage were assayed by real-time PCR using lysed phage DNA directly as template ( $\mathrm{Yu}$ et al., 2007). PCR relative cycle threshold $(\mathrm{Ct})$ values (100 minus $\mathrm{Ct}$.) were plotted against IgG concentration. Phage bindings are indicated by low $\mathrm{Ct}$ values.

\section{Inhibition ELISA}

For inhibition ELISA, MS 95-2 IgG at a concentration of $20 \mu \mathrm{g} / \mathrm{ml}$ was pre-incubated with the indicated amounts of competitive synthetic peptide 3-3 or irrelevant peptide for $30 \mathrm{~min}$ at room temperature and the mixture was added to wells of ELISA plates pre-coated with EBNA1 protein antigen $(50 \mu \mathrm{g} / \mathrm{ml})$ (DevaTal, Inc., Hamilton, NJ). Bound IgG was detected by incubation of a 1:500 dilution of antihuman IgG-HRP (Sigma) for $1 \mathrm{~h}$ followed by ABTS color reaction as described above. EBNA1 peptide competed with EBNA1 protein for binding to MS 95-2 IgG, whereas the irrelevant peptide (2-6-12, HVQLAPPIALRH) did not. The higher the concentration of Peptide 3-3 that is added, the less 95-2 IgG was observed binding to the EBNA-1 coated on the plate.

\section{Phage Mediated Immuno-PCR for Screening Multiple CSF}

MS and control CSF at the IgG concentration of $1 \mu \mathrm{g} / \mathrm{ml}$ were added to wells of Reacti-Bind ${ }^{\mathrm{TM}}$ protein A coated clear strip plate (Thermo Fisher/Pierce, Waltham, MA) and incubated at room temperature for $2 \mathrm{~h}$. The wells were then blocked with $3 \% \mathrm{BSA}$ for $2 \mathrm{~h}$ and incubated for $1 \mathrm{~h}$ with phages 3-2 and 3$3\left(10^{8} /\right.$ well $)$ in $1 \%$ BSA, respectively. After washing with TBST, bound phages were collected by heating the wells with
$50 \mu$ of deionized water at $95^{\circ} \mathrm{C}$ for $15 \mathrm{~min}$. Phage solution $(4 \mu \mathrm{l})$ was used as templates for real-time PCR. For phage mediated real-time PCR, specific primers for M13 phage were used ( $\mathrm{Yu}$ et al., 2006a). All real-time PCR was performed in an Applied Biosystems 7500 Fast Real-Time PCR system (Applied Biosystems, Forest City, CA). Each PCR reaction $(20 \mu \mathrm{l})$ consisted of $1 \mathrm{X}$ power SYBR® Green master mix, $750 \mathrm{nM}$ of each primer and $4 \mu \mathrm{l}$ of phage template. A dissociation-curve analysis was performed at $95{ }^{\circ} \mathrm{C}$ for $15 \mathrm{~s}$, $60{ }^{\circ} \mathrm{C}$ for $1 \mathrm{~min}$ and $95^{\circ} \mathrm{C}$ for $15 \mathrm{~s}$. A control reaction without template and standard curve analysis were included in each run. Bound phages were calculated based on standard curve analysis. The thermal cycle conditions included $95{ }^{\circ} \mathrm{C}$ for $10 \mathrm{~min}$, followed by 40 cycles of $95^{\circ} \mathrm{C}$ for $15 \mathrm{~s}$ and $60{ }^{\circ} \mathrm{C}$ for $45 \mathrm{~s}$. The $100 \mathrm{bp}$ amplicon was confirmed by electrophoresis.

\section{IEF Immunoblot of MS CSF with EBNA1 Phage Peptide Probe}

CSF $(200-500 \mu \mathrm{l})$ was centrifuged through an Amicon Ultra $0.5 \mathrm{ml} 30 \mathrm{~K}$ cellulose centrifugal filter unit (Amicon, MilliporeSigma, Burlington, MA) at $14,000 \times \mathrm{g}$ for $30 \mathrm{~min}$ at room temperature before IEF using the SPIFE® IgG IEF kit (Helena Laboratories, Beaumont, TX) and a SPIFE 3000 electrophoresis analyzer. Wicks were soaked in an anode $(0.3 \mathrm{M}$ acetic acid) or cathode $(1 \mathrm{M} \mathrm{NaOH})$ solution and applied to the edge of a SPIFE® IgG IEF gel. Five microliters of MS $\mathrm{CSF} / \mathrm{sera}(3-5 \mu \mathrm{g}$ IgG for phage probe and $100 \mathrm{ng} \operatorname{IgG}$ for alkaline phosphatase (AP)-conjugated anti-human IgG probe) (Vector Lab) were loaded into wells of an SPIFE IEF gel. After electrophoresis at $700 \mathrm{~V}$ for $1 \mathrm{~h}$ at $15^{\circ} \mathrm{C}$, samples were transferred to PVDF membranes (Helena Lab) for $45 \mathrm{~min}$, followed by blocking in Helena blocking agent $(1 \mathrm{~g}$ bovine milk protein $/ 50 \mathrm{ml} 1 \mathrm{X}$ TBS) for $1 \mathrm{~h}$ at room temperature. Membranes were incubated with the respective phage peptides at concentrations ranging from $5.0 \times 10^{10}$ to $1.5 \times 10^{11}$ $\mathrm{pfu} / \mathrm{ml}$ in 1:10 Helena blocking agent/TBST (blocking buffer) at room temperature for $2 \mathrm{~h}$. After washing with TBST membranes were incubated with mouse anti-M13 mAb at a 1:500 dilution in blocking buffer, followed by incubation with 1:500 dilution of AP conjugated anti-mouse IgG at room temperature for $1 \mathrm{~h}$. Membranes were developed with NBT/BCIP substrate (Vector Labs). For control blots, membranes were incubated for $1 \mathrm{~h}$ with 1:1000 dilutions of AP-anti-human IgG $(\mathrm{H}+\mathrm{L})$ in blocking buffer, followed by NBT/BCIP detection.

\section{Peptide Synthesis}

EBV-related peptides (3-2 and 3-3) that were selected by panning with the MS 95-2 IgG were commercially synthesized by Sigma Genosys (The Woodlands, TX), and were more than $90 \%$ pure as determined by reverse-phase high- 
performance liquid chromatography. Each peptide contains 16 amino acids with the specific 12-mer peptide sequence being analyzed followed by the $\mathrm{C}$ terminal peptide sequence GGGC (GGGS is the spacer sequence between the peptide and the phage pIII minor protein). The serine residue was replaced with cysteine to facilitate coupling the thiol group in the resulting peptide to the maleimide-activated ELISA plate (Pierce Thermo Fisher). The C-terminus carboxyl group on the cysteine residue was amidated to block the negative charge.

\section{Statistics}

Student's $t$ test was used to compare the mean between two groups. Mann-Whitney nonparametric test was performed for IPCR screening MS CSF using GraphPad Prism 6.0 (GraphPad Software Inc., San Diego). Other analyses are from specialized software packages and are cited above.

\section{Results}

\section{Phage Peptides Selected by MS Plaque IgG Share Sequence Homology with EBNA1 and EBNA2}

There are continually mounting epidemiological data regarding the association between EBV infection and MS (Laurence and Benito-Leon, 2017) (including the antibody recognition of EBV antigens (Almohmeed et al., 2013)). In this background, to identify antigenic targets of the antibody response of IgG in MS, we panned phage-displayed random peptide libraries on IgG that was purified from plaque-periplaque white matter of an acute MS brain using similar panning protocols (Yu et al., 2011a; Graner et al., 2020). A total of four unique phage peptides were identified. Table 1 lists the peptide sequences and target proteins aligned in the Swiss-Prot data base. We selected the two peptides which showed sequence homologies to EBV nuclear antigens $1 \& 2$ (EBNA1 and EBNA2) for further investigation. These two peptides were further confirmed by searching the peptides for homology against the EBV virome/proteome (Fig. 1a \&d). Note that of the 20 phage clones sequenced, Pep 3-3 represented 2 of those, and Pep 3-2 represented 13 of the clones. The remaining 2 peptides, peptide 3-19 which has homologies to minor capsid protein L2 (human papillomavirus type 44), and peptide 3-20 homologous to Human coronavirus spike glycoprotein each represented one clone and were not studied further.

We analyzed the antigenic potential of Peps 3-3 and 32, along with their corresponding sequences in EBNA1 and EBNA2 proteins, using a variety of algorithms. For Pep 3-3 and EBNA1, we see that based on methods of Kolaskar and Tongaonkar (Kolaskar and Tongaonkar, 1990), (http:// imed.med.ucm.es/Tools/antigenic.pl) portions of the midC-terminus of EBNA1 $1_{386-416}$ would be considered antigenic, including the determinant PFFHPVGE. The C-terminus of Pep 3-3 shows potential antigenic propensity (Fig. 1b, c) and this is a region of sequence homology between Pep 3-3 and EBNA1 (Fig. 1a). Both Pep 3-2 and the corresponding region of EBNA2 (EBNA 263-286) have average antigenic propensities above threshold with higher scores at the peptides' C-termini despite no noted specific antigenic determinants (Fig. 1e, f). Further, additional multiple epitope prediction programs suggest that homologous regions of EBNA1 $1_{386-416}$ and Pep 3-3, and of EBNA2 $263-286$ and Pep 3-2, are potential B cell epitopes (Supplemental Figs. $1 \&$ 2, Supplemental Table 1).

\section{Predicted Structural Relationships between EBNA1 ${ }_{386-416}$ and Pep 3-3, and between EBNA2 263- 286 and Pep 3-2}

There is no definitive structural information available concerning the region of EBNA1 (EBNA1 $1_{386-416}$ ) that is homologous to Pep 3-3. Protein Database Entries covering a portion of the EBNA1 protein are in the context of an EBNA1 peptide in the pocket of an HLA molecule being presented to a $\mathrm{T}$ cell receptor. EBNA2 $263-286$ (homologous to Pep 3-2) also lacks structural data.
Table 1 Peptide sequences identified by MS brain IgG antibodies and their homologous proteins

\begin{tabular}{lllll}
\hline $\begin{array}{l}\text { Peptide } \\
\text { ID }\end{array}$ & Sequence & Homology to known proteins & Identities $^{\mathbf{1}}$ & $\begin{array}{l}\text { Sequence } \\
\text { range }^{\mathbf{2}}\end{array}$ \\
\hline $\mathbf{3 - 2}$ & SQSGPTIFYNLA & EBNA-2 (Human herpesvirus 4) & $5 / 6(83 \%)$ & $170-175$ \\
$\mathbf{3 - 3}$ & AESRRPFFEPFM & EBNA-1 (Human herpesvirus 4) & $6 / 7(86 \%)$ & $402-408$ \\
$\mathbf{3 - 1 9}$ & FNPSFAKMGNSL & $\begin{array}{c}\text { Minor capsid protein L2 (Human } \\
\text { papillomavirus type 44) }\end{array}$ & $5 / 5(100 \%)$ & $158-162$ \\
$\mathbf{3 - 2 0}$ & SALTSAVSGSAA & $\begin{array}{c}\text { Spike glycoprotein (Human coronavirus } \\
\text { 229E) }\end{array}$ & $6 / 6(100 \%)$ & $761-766$ \\
\hline
\end{tabular}

${ }^{2}$ : Location of the target sequence where the peptide aligned

${ }^{1}$ : Percent of identical amino acid residues to target protein 
a

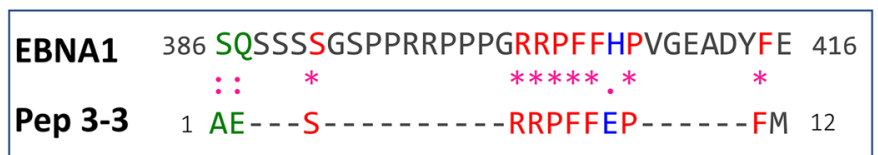

b

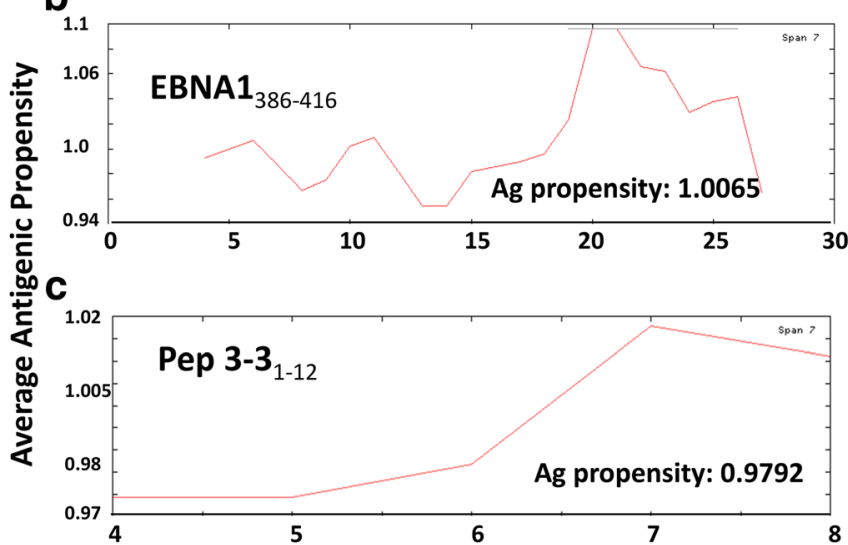

d

EBNA2 263 HQSTPNDPDSPEPRSPTVFYNIP 286

Pep 3-2 1 SQS-.....-_GPTIFYNLA 12

e

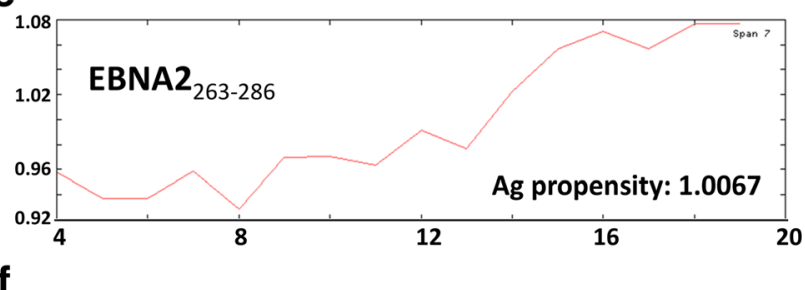

f

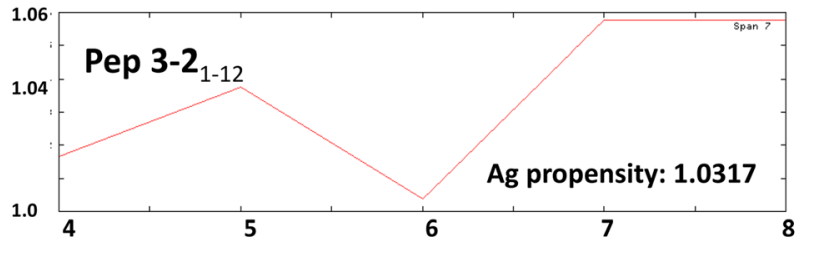

\section{Sequence Number}

Fig. 1 Phage peptides selected by MS brain plaque IgG antibodies share high sequence homologies with Epstein-Barr Virus Nuclear Antigen-1 (EBNA1) and EBNA2 and are predicted with high antigenic propensity. Two unique phage peptides (Pep 3-3 and Pep 3-2) were identified by panning phage-displayed random peptide libraries with $\mathrm{IgG}$ antibodies purified from plaques of a MS brain with acute disease. CLUSTAL W alignment was performed for sequence homology alignments. a. Pep 3-3 is shown with identical (“*”, red lettering; 8/12), strongly similar (“:”, green lettering; 2/12), and weakly similar (“.”, blue lettering; 1/12) residues designated over the EBNA1 amino acid sequence from 386 to 416 . This phage accounted for 2 of the 20 phage peptides sequenced. b. Graphic presentation of predicted antigenic peptide in EBNA1 386-416 (SQSSSSGSPPRRPPPGRRPFFHPVGEADYFE). Average Antigenic

To compare the EBNA proteins regions with their homologous peptides, we used PepFold 3.5 to render possible structures for three-dimensional alignments of the homologous protein sequences and the phage peptides. For EBNA1 ${ }_{386-416}$, the amino acid residues in that peptide's positions 17-23 represent the longest contiguous stretch of homology with Pep 3-3 (Fig. 1a).

In Fig. 2a, these charged and aromatic amino acids protrude from the plane of the peptide toward the reader, suggesting an exposed surface, portions of which are considered potential B cell/antibody recognition epitopes. Likewise, the residues of Pep 3-3 that show a similar structural configuration (Arg5, Pro6, Phe7, Phe8, Pro10, Fig. 2b) to the homologous stretch in EBNA1 $_{386-416}$ (Arg18, Pro19, Phe20, His22, Pro23, Fig. 2a) are also within portions of predicted epitopes. For EBNA2 $263-$ 286 and Pep 3-2, we see positional alignments of aromatic and polar amino acids (Pro16, Thr17, Pro13, Phe19 in the arrangement of EBNA2 $263-286$ (Fig. 2c) with Pro5, Thr6, Tyr9, and Phe8 in Pep 3-2 (Fig. 2d). Again, these amino acids are depicted as protruding from the plane of the image toward the reader, and they correspond to regions that may be $\mathrm{B}$ cell/antibody epitopes.
Propensity $=1.0065$; Antigenic determinant $=$ PFFHPVGE c . Graphic presentation of predicted antigenic peptide for Pep 3-3 (AESRRPFFEPFM). Average Antigenic Propensity $=0.9792$; No noted antigenic determinants. d. CLUSTAL W alignment of Pep 3-2 with EBNA2. Pep 3-2 is shown with identical (“*”, red lettering; 7/12), strongly similar (“:”, green lettering; 2/12), and weakly similar (“.”, blue lettering; 2/12) residues designated over the EBNA2 amino acid sequence from 263 to 286 . This phage accounted for 13 of the 20 phage peptides sequenced. e. Graphic presentation of predicted antigenic peptide in EBNA2 263-286 (HQSTPNDPDSPEPRSPTVFYNIP). Average Antigenic Propensity = 1.0067; no noted antigenic determinants. f. Graphic presentation of predicted antigenic peptide for Pep 3-2 (SQSGPTIFYNLA). Average Antigenic Propensity $=1.0317$; No noted antigenic determinants

\section{The Specificity of Phage Peptides for MS Plaque IgG}

To validate the specificity of the selected phage peptides, we performed ELISAs and showed that these two EBNA-related peptides bound specifically to MS brain IgG antibodies used in the original panning (Fig. 3a). Furthermore, dose response phage-mediated immune-PCR demonstrated that these phage peptides bound to panning target antibodies in a dosedependent manner (Fig. 3b).

\section{Phage Peptide 3-3 (EBNA1 ${ }_{386-416}$ Epitope) Inhibits Binding of EBNA1 Recombinant Protein to Panning MS Brain IgG}

We showed that phage peptide 3-3 has high sequence and structural homology to EBNA1, along with predicted epitope potential. To demonstrate that Pep 3-3 indeed resembles an epitope of EBNA1, we synthesized peptide 3-3 and carried out inhibition ELISA using commercial EBNA1 protein. MS brain IgG 95-2 at a final concentration of $20 \mu \mathrm{g} / \mathrm{ml}$ was incubated with varying concentrations of peptide 3-3 or irrelevant 


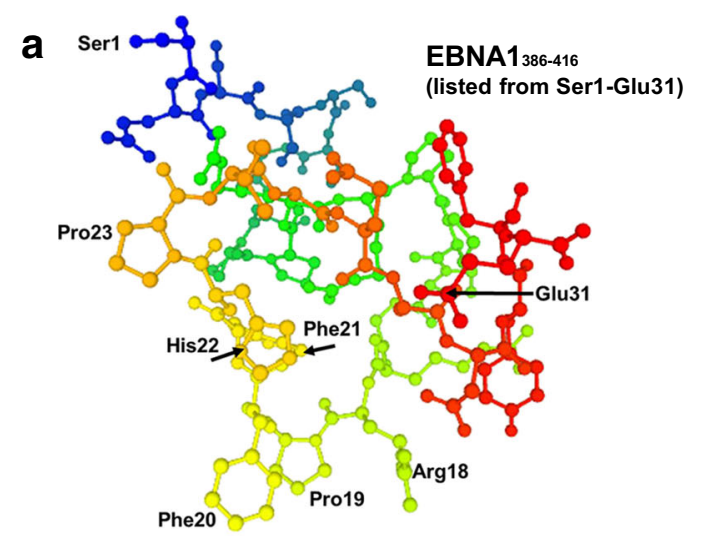

b

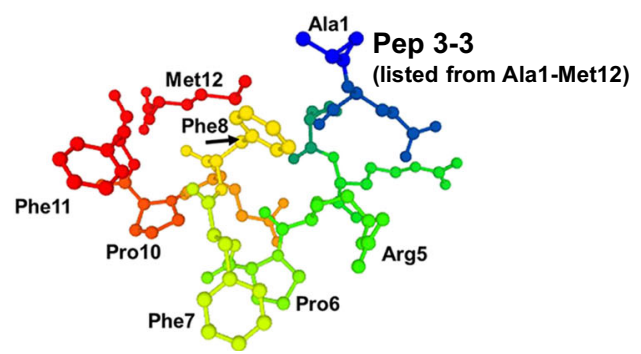

Fig. 2 Predicted structural relationships between EBNA1 $1_{386-416}$ and Pep 3-3, EBNA2 263-286 and Pep 3-2. Using PepFold 3.5 (http://bioserv.rpbs. univ-paris-diderot.fr/services/PEP-FOLD3/), we rendered potential structural information comparing the peptides. a, b. Ser1 and Glu31 (first and last residues for EBNA1 ${ }_{386-416}$ ) and Ala1 and Met12 (first and last residues for Pep 3-3) are shown for orientation. Amino acid residues of interest as potentially antigenic are shown as coming out of

peptide (2-6-12, HVQLAPPIALRH) and were transferred to ELISA plates pre-coated with EBNA1 protein. Bound $\operatorname{IgG}$ were detected with HRP-conjugated anti-human IgG. Pep 33 competed with EBNA1 protein for binding to MS 95-2 IgG, whereas the irrelevant peptide did not. The higher the

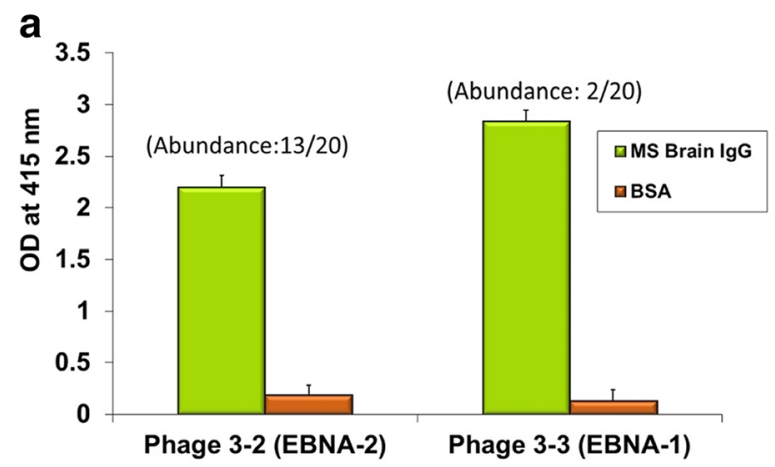

Fig. 3 Phage peptides 3-3 and 3-2 show specific binding to panning MS brain antibodies. a. ELISA demonstrating specific bindings of the selected phage peptides to the MS brain antibodies used in the panning step. BSA coating serves as negative control. The abundance shown in the parenthesis indicates the frequency of the peptide out of total number of phage clones sequenced. b. Dose response phage IPCR showing specific binding of phage peptides to panning MS brain antibody 95-2 IgG. Wells

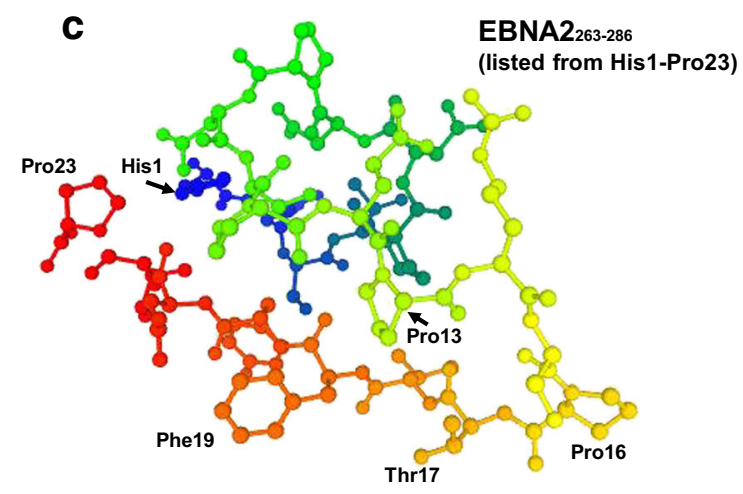

d

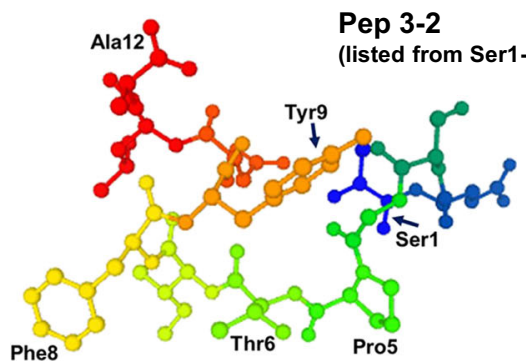

the plane of the figure toward the reader ${ }_{18} \mathrm{RPFFHP}_{23}$ in EBNA $1_{386-416}$, and ${ }_{5} \mathrm{RPFF}[\mathrm{E}] \mathrm{PF}_{11}$ in Pep 3-3). c, d. His1 and Pro23 (first and last residues for EBNA2 263-286) and Ser1 and Ala12 (first and last residues for Pep 3-2) are shown for orientation. Amino acid residues of interest as potentially antigenic are shown as coming out of the plane of the figure toward the reader ${ }_{13} \mathrm{P}[\mathrm{RSP}] \mathrm{T}[\mathrm{V}] \mathrm{F}_{19}$ in $\mathrm{EBNA} 2_{263-286}$ and ${ }_{5} \mathrm{PT}[\mathrm{I}] \mathrm{FY}{ }_{9}$ in Pep 3-2)

concentration of peptide 3-3 that is added, the less 95-2 IgG was observed binding to the EBNA-1 coated on the plate (Fig. 4). The difference between bindings of pep 3-3 and control peptide to MS brain IgG was significant $(p=0.018$, paired t-test).

b

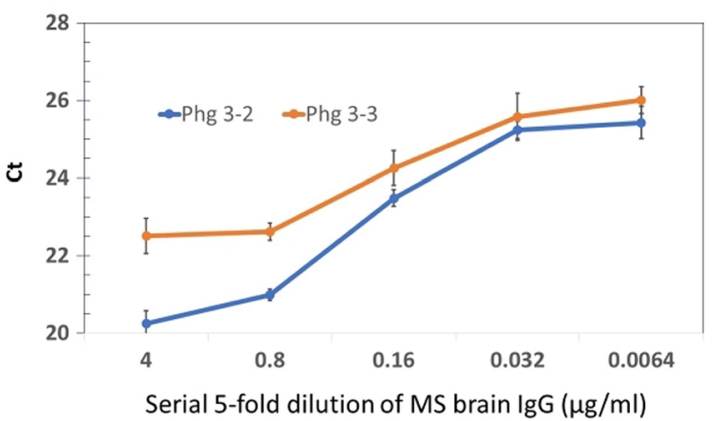

of protein A coated plate were added with panning target MS antibodies (5-fold serial dilutions) and incubated with equal amount of each phage $\left(10^{7} /\right.$ well). Bound phage were assayed by real-time PCR using lysed phage DNA directly as template. PCR relative cycle threshold $(\mathrm{Ct})$ values (100 minus Ct.) were plotted against IgG concentration. Avidly bound phage are indicated by low $\mathrm{Ct}$ values. Each data point is the average of two independent measurements 


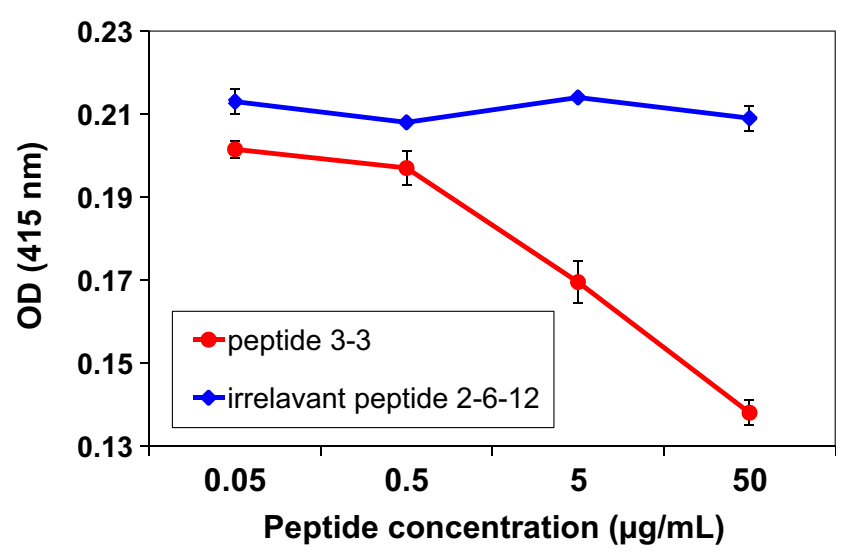

Fig. 4 EBNA1 epitope (peptide 3-3) inhibits binding of EBNA1 protein to MS 95-2 IgG. ELISA wells were coated overnight with recombinant EBNA-1 protein at $50 \mu \mathrm{g} / \mathrm{ml}$. MS brain IgG 95-2 at a final concentration of $20 \mu \mathrm{g} / \mathrm{ml}$ were incubated with varying concentrations of synthetic peptide 3-3 or irrelevant peptide (2-6-12) and were transferred to the plate pre-coated with EBNA-1 protein. Bound $\operatorname{IgG}$ were detected with HRP-conjugated anti-human IgG. Pep 3-3 competed with EBNA1 protein for binding to MS 95-2 IgG, whereas the irrelevant peptide did not. The higher the concentration of Peptide 3-3 that is added, the less 95-2 IgG was observed binding to the EBNA1 coated on the plate. The difference between bindings of pep 3-3 and control peptide was significant $(p=0.018$, paired t-test $)$

\section{MS CSF Contained Significantly Higher Levels of Antibodies Bound to EBNA1 Epitope (Pep 3-3) Compared to EBNA2 Epitope (Pep 3-2)}

We applied highly sensitive phage-mediated IPCR to assess the binding specificity of putative EBNA1/2 epitopes (represented by phage peptides 3-3 and 3-2) to MS CSF IgG (Yu et al., 2011b). We screened a total of 46 MS CSF 5 IC CSF. Table 2 lists characteristics of these patients. Phage peptides 3-3 and 3-2 were added to MS and IC CSF coated wells of protein A plates. Bound phage were lysed and detected by real-time PCR (Yu et al., 2007), with the number of bound phage determined. CSF IgG from MS patients showed significantly higher binding to EBNA1 epitope/phage peptide 3-3 compared to IC CSF ( $p=0.0075$, Mann-Whitney nonparametric test) (Fig. 5a); in contrast, there was no statistical difference between MS and IC CSF for bindings to EBNA2 epitope/phage peptide 3-2 (Fig. 5b).

\section{EBNA1 Epitope Pep 3-3 Reacts with Intrathecal IgG Antibodies from Patients with MS}

To further evaluate the intrathecal $\operatorname{IgG}$ reactivity to the putative EBNA1 epitope Pep 3-3, we performed isoelectric focusing (IEF) immunoblotting on selected MS CSF. MS CSF samples were separated on SPIFE IEF agarose gels. Proteins were transferred to PVDF membranes, and the blots were probed with EBNA1 phage peptide 3-3 followed by antiM13 primary antibody, then by anti-mouse secondary antibody, with colorimetric detection. EBNA1 epitope Pep 3-3 selected by panning with MS brain IgG was recognized by multiple high-density IgG bands in both CSF and serum from representative MS patients. (Fig. 6a). These results suggest that the EBNA1 epitope is reactive to MS intrathecal antibodies corresponding to oligoclonal bands. We further performed dose-dependent phage-IPCR and showed that EBNA1 epitope Pep 3-3 had significantly higher bindings to MS CSF than paired serum, demonstrating the preferential intrathecal $\operatorname{IgG}$ reaction in MS (Fig. 6b-d).

\section{Discussion}

We have shown in this study that phage peptides discovered by panning with $\operatorname{IgG}$ antibodies derived from a lesion in an acute MS brain (MS 95-2 IgG) shared high sequence and putative structural homologies with Epstein-Barr virus antigens EBNA1 and EBNA2. The phage peptides, termed Pep 3-3 and Pep 3-2, respectively, are homologous with the sequences EBNA1 $1_{386-416}$ and EBNA2 263-286. We demonstrated predicted $\mathrm{B}$ cell epitope potential for the peptides and for the homologous EBNA1/2 protein regions. IPCR assays showed that phage peptide/Pep 3-3 showed significantly higher binding to MS CSF IgG than phage peptide/Pep 3-2, while Pep 32 had higher binding (but statistically non-significant) to IC CSF IgG. Furthermore, we show that EBNA1 epitope/Pep 33 could block MS 95-2 IgG reactivity with EBNA1 protein, and that phage/phage peptide Pep 3-3 was recognized by MS intrathecal and serum IgG antibodies and oligoclonal bands.

EBNA1 is critical for maintaining viral replication and maintenance of the viral genome (Wu et al., 2002; ShannonLowe and Rickinson, 2019). EBNA1 is an important viral protein expressed in Burkitt's Lymphoma (Rowe et al., 2014) as well as during various latency phases (Latency I, I/II, II, III) in EBV-associated malignancies (Shannon-Lowe and Rickinson, 2019). EBNA1 has long been recognized as an antigen in MS in the contexts of both antibody (Lunemann et al., 2008a; Farrell et al., 2009; Comabella et al., 2010; Nociti et al., 2010; Sundqvist et al., 2012; Mameli et al., 2014; Honarmand et al., 2015; Hecker et al., 2016; Tengvall et al., 2019) and $\mathrm{T}$ cell targets (Lunemann et al., 2006; Ramasamy et al., 2020). Some studies include both B and T cell responses to EBNA1 (Lunemann et al., 2008b; Pender et al., 2009; Lunemann et al., 2010; Comabella et al., 2012; Mameli et al., 2016; Pender et al., 2017). In some cases where peptide antigens/targets were used in assays, the region of EBNA1 covered by Pep 3-3 is included (Lunemann et al., 2006; Lunemann et al., 2008a; Lunemann et al., 2008b; Lunemann et al., 2010; Sundqvist et al., 2012; Mameli et al., 2014; Mameli et al., 2016). Hecker et al. (Hecker et al., 2016) using a high-density peptide array of overlapping EBNA1 peptides (among many others) found that antibodies from both 
Table 2 Characteristics of patients

\begin{tabular}{llllllll}
\hline Sample ID & Age & Sex & Diagnosis & Sample ID & Age & Sex & Diagnosis \\
\hline MS 02-02 & 38 & M & RRMS & MS 03-13 & 45 & F & RRMS \\
MS 02-06 & 42 & F & RRMS & MS 04-01 & 42 & F & RRMS \\
MS 02-07 & 54 & F & RRMS & MS 04-03 & 44 & M & RRMS \\
MS 02-08 & 30 & F & RRMS & MS 04-04 & 31 & F & RRMS \\
MS 02-10 & 45 & F & RRMS & MS 04-05 & 56 & F & RRMS \\
MS 02-11 & 22 & F & RRMS & MS 04-06 & 30 & M & RRMS \\
MS 02-14 & 51 & F & RRMS & MS 04-07 & 56 & F & PPMS \\
MS 02-15 & 26 & F & RRMS & MS 04-08 & 28 & F & RRMS \\
MS 02-16 & 48 & F & RRMS & MS 04-09 & 48 & M & RRMS \\
MS 02-17 & 33 & F & RRMS & MS 05-01 & 52 & M & RRMS \\
MS 02-18 & 41 & F & RRMS & MS 05-02 & 53 & F & RRMS \\
MS 02-21 & 54 & F & RRMS & MS 05-03 & 30 & F & RRMS \\
MS 02-22 & 49 & F & RRMS & MS 05-04 & 57 & F & RRMS \\
MS 02-24 & 39 & F & SPMS & MS 05-05 & 53 & M & RRMS \\
MS 03-01 & 25 & F & RRMS & MS 05-06 & 62 & M & PPMS \\
MS 03-02 & 49 & F & RRMS & MS 05-07 & 40 & M & RRMS \\
MS 03-03 & 50 & M & RRMS & MS 05-08 & 46 & F & RRMS \\
MS 03-04 & 22 & F & RRMS & MS 05-10 & 61 & F & RRMS \\
MS 03-05 & 51 & F & RRMS & MS 06-01 & 65 & M & RRMS \\
MS 03-07 & 42 & F & RRMS & IC 06-01 & 66 & M & SSP* \\
MS 03-08 & 48 & F & RRMS & IC 06-02 & 36 & F & SSPE \\
MS 03-09 & 40 & F & RRMS & IC 04-01 & 39 & F & Behcet's disease \\
MS 03-10 & 45 & F & RRMS & IC 04-05 & 57 & M & Cryptococcal meningtitis \\
MS 03-11 & 47 & F & RRMS & IC 07-02 & 49 & M & Viral meningitis \\
\hline
\end{tabular}

*SSPE: Subacute sclerosing panencephalitis sera and CSF of RRMS and/or PPMS patients reacted with EBNA1 $_{391-410}$ or EBNA1 ${ }_{392-411}$. These amino acid ranges

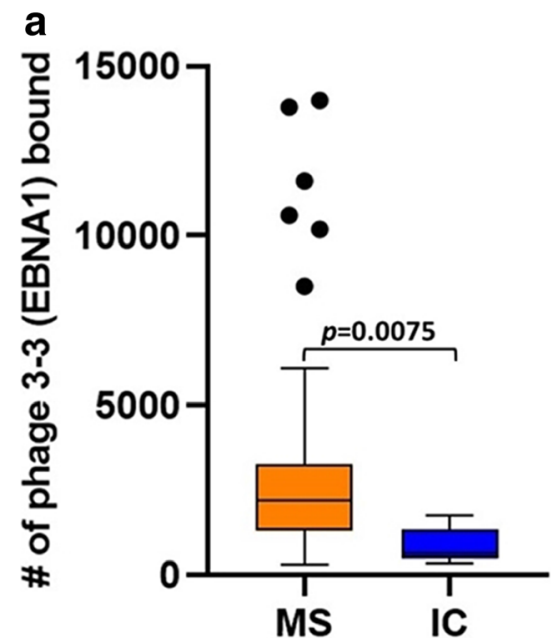

Fig. 5 EBNA1 and EBNA2 epitope-specific antibodies are detected differentially in MS CSF, and EBNA1/Pep 3-3 has significantly higher bindings to MS CSF IgG compared to EBNA2/Pep 3-2. EBNA1/Phage 3-3 (Pep 3-3) and EBNA2/Phage 3-2 (Pep 3-2) at concentrations of $10^{8} /$ well were added to Protein A wells pre-coated respectively with $46 \mathrm{MS}$ $\mathrm{CSF}$ and $5 \mathrm{IC} \mathrm{CSF}$ (at IgG concentration of $1 \mu \mathrm{g} / \mathrm{ml}$ ). Bound phages were cover an RRPFF motif that appears central to Pep 3-3 in its homology with EBNA1 $1_{386-416}$ and is likely part of the epitope

b

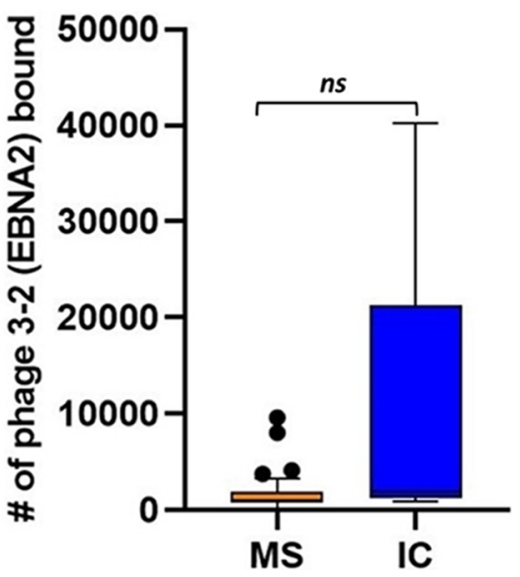

detected by IPCR. Significantly higher bindings of MS CSF IgG to phage Pep 3-3 (EBNA1) compared IC CSF are shown in a ( $p=0.0075$; MannWhitney nonparametric test). For phage 3-2 (EBNA2), there is no significant difference for bindings between MS and IC CSF. Phage counts (averages of duplicate values) are available in Supplemental Table 2 
a

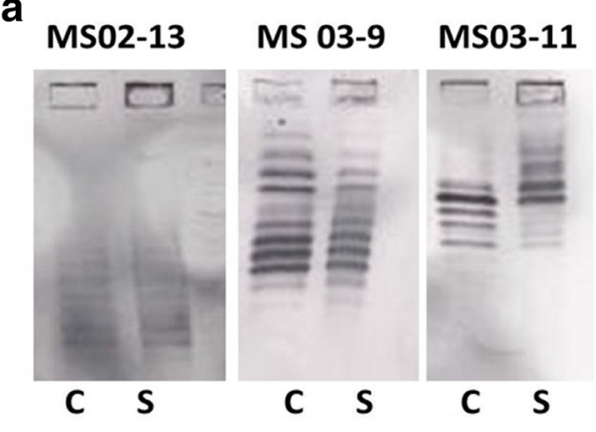

C

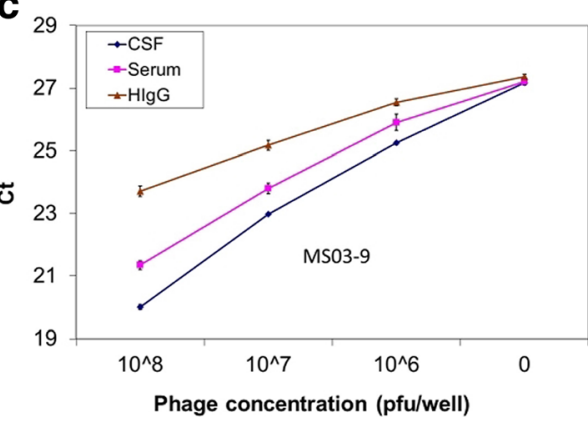

Fig. 6 EBNA1 epitope (phage peptide 3-3) was recognized by intrathecally synthesized IgG in MS. a. IEF-immunoblots demonstrating EBNA1 epitope (phage peptide 3-3) reacts to oligoclonal IgG antibodies in MS. Paired MS CSF (C) and serum (S) (3-5 $\mu$ g total $\mathrm{IgG})$ from three patients (MS02-13, MS03-9, MS03-11) were resolved on agarose IEF gels and transferred to PVDF membranes. Blots were probed with EBNA1 phage peptide $3-3\left(10^{10} \mathrm{pfu} / \mathrm{ml}\right)$ and incubated with mouse anti-M13 antibody followed by AP-anti-mouse antibody detection. Peptides selected by MS IgG recognized multiple high density IgG bands in both CSF and serum. b-d. Dose-dependent phage-IPCR demonstrates EBNA1 epitope (phage peptide 3-3) binds to intrathecally synthesized $\mathrm{IgG}$ in MS. Paired MS serum and CSF, as well as pre-immune human IgG

recognized by the various MS patient IgG used here (IgG from brain itself, and from sera and CSF).

In a study going back over two decades (Rand et al., 1998) CSF IgG from 5 of 14 MS patients selected the motif RRPFFX (where $\mathrm{X}=\mathrm{H}, \mathrm{R}, \mathrm{M}, \mathrm{L}, \mathrm{N}$ or I) from a 6-mer phage library ( $>10^{7}$ possible sequences). Using a biotinylated peptide in the context of the phage pIII protein, the peptide could be detected bound to certain OCBs from MS CSF, indicating the presence of selective antibodies. A GenBank search at that time found the motif in the EBV protein EBNA1, and in the chaperone protein $\alpha$ B crystallin (CRYAB/HSPB5). Current BLASTp searches reveal scores of matches in many proteins, but at least $10 \%$ of the hits are to EBNA1 from various EBV isolates, suggesting that EBNA1 and the motif are highly represented. In a follow-up to those studies, the same group (Rand et al., 2000) used the aforementioned peptide to probe blots of more MS patient CSF-derived OCBs for reactivity to the EBNA1 peptide motif. Five of 15 MS patients' OCBs (CSF samples from a different repository) again showed significant reactivity to the peptide, with no controls reacting (and all were serologically EBV positive). b

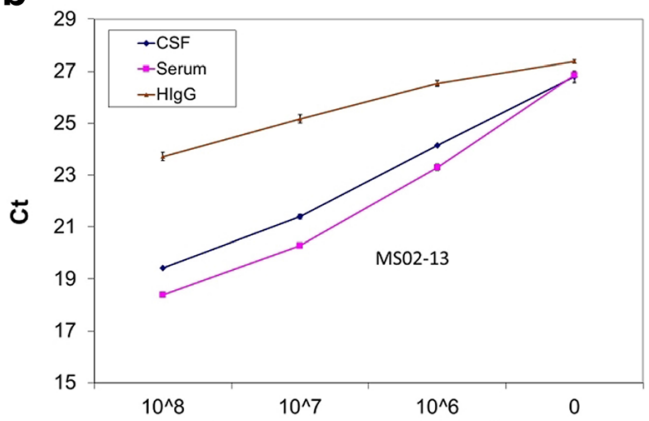

d

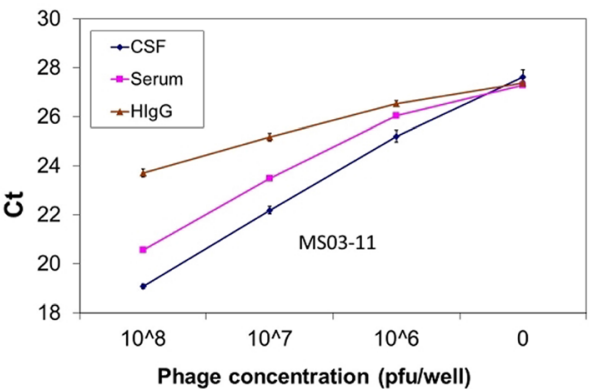

control $(50 \mu \mathrm{l}$ at $\mathrm{IgG}$ concentration of $1 \mu \mathrm{g} / \mathrm{ml})$, were coated in duplicate wells of protein A-plates before addition of the corresponding phage peptides (serial 10-fold dilutions starting with $10^{8} \mathrm{pfu} /$ well). Bound phage was determined by real-time PCR. Phage peptide bound significantly higher in number to IgG in CSF than in serum in a dose-dependent manner $(p=0.0058$ for MS02-13; $p=0.0445$ for MS03-9; $p=0.0246$ for MS03-11; unpaired t-test). Preimmune human IgG served as negative control. Experiments were performed at least twice. Error bars represent SD. B, patient MS02-13; C, patient MS03-9; D, patient MS03-11. Data represent at least three independent experiments. Lower $\mathrm{Ct}$ values indicate more phage bound

Our studies here showed that MS brain IgG antibodies show activities to both EBNA1 and EBNA2 epitopes, while IgG in the CSF from multiple patients largely react with the EBNA1 epitope. This was verified with reactivity of the EBNA1 Pep 3-3 with OCBs in MS patient CSF and sera. This may be the first time that an EBNA1 epitope has been recognized by MS patients' antibodies culled from a brain lesion as well as recognition by OCBs from CSF and sera, and underscores the potentially significant role played by EBV in MS through EBNA1.

The roles of EBNA2 in MS etiology are less clear, with indications that its transcription factor activities may be important (Ricigliano et al., 2015; Afrasiabi et al., 2019). After phage peptide selection by MS 95-2 IgG, we found relatively few MS patient CSF IgG interactions with Pep 32 (EBNA2 $263-286$ homolog) suggesting it was not as prominent of an antigen/epitope in the broader MS patient population. While EBNA2 genetic variants may have some impact on the disease (Mechelli et al., 2015), it is unclear how this may relate to antigenicity, and should be an area of further study. 
A recent cohort study consisting of more than 25,000 Scandinavian patients with infectious mononucleosis (IM) who were followed up for the occurrence of MS (Nielsen et al., 2007) and a meta-analysis of smaller previous studies on the association of IM and MS reported that individuals with a history of IM have a $>2$-fold increased risk of developing MS compared to subjects who acquired the virus without symptoms (Thacker et al., 2006). Most healthy virus carriers maintain anti-EBNA-1 as well as anti-gp350 and anti-VCA (viral capsid antigen) IgG responses during latent EBV infection (Lunemann et al., 2007), and these responses are used diagnostically to assess whether individuals have been infected with EBV (Tierney et al., 2007).

The necessity and sufficiency of EBV infection as a causative agent in MS remains a point of debate, particular given the widespread nature EBV infection in humans (Owens and Bennett, 2012; Hutchinson, 2013; Pakpoor et al., 2013; Pakpoor and Ramagopalan, 2013; Salzer and Myhr, 2013; Burnard et al., 2017). Nonetheless, large prospective seroepidemiological studies analyzing antibody responses via standard diagnostic ELISAs to suspected antigens have consistently demonstrated that MS patients are almost universally seropositive for EBV. These data support the argument that infection with $\mathrm{EBV}$ is a possible requirement for the development of MS (Lunemann et al., 2007). Among more than 80 lytic and 8 latent EBV gene products, the latency-associated EBNA1 is the only protein consistently expressed in infected proliferating memory $\mathrm{B}$ cells in healthy virus carriers (Hochberg et al., 2004). IgG responses to the EBV latent antigen EBNA2 peak during acute infection and are directed against latent and lytic antigens (Cohen, 2000). EBNA1 is thus the only EBV antigen consistently expressed in proliferating cells with latent $\mathrm{EBV}$ infection in healthy virus carriers. It represents a key target antigen for $\mathrm{CD}^{+} \mathrm{T}$ cell-mediated immune control mechanisms of EBV infection in healthy individuals (Lunemann et al., 2007). The persistent detection of EBNA1 under these circumstances could imply a role for the antigen as a trigger for MS under the appropriate conditions (e.g., involving a wide variety of environmental and/or genetic factors including HLA (human leukocyte antigen) type) (Alfredsson and Olsson, 2019).

There are multiple links between MS and EBV infection (reviewed in (Haahr and Hollsberg, 2006)): studies of MSand EBV-epidemiology; prospective and retrospective analyses of EBV-serology; EBV DNA sequences in blood and tissues; the specificity of antibodies amongst oligoclonal bands in MS patients; and the results from antiviral chemotherapy of MS patients. Further, regarding EBNA1 and EBNA2, the geometric mean titers of serum antibodies to EBNA1 were significantly higher in MS patients when compared with matched controls. Though the geometric mean titers to EBNA2 were not significantly higher among MS cases when compared with matched controls, they were significantly elevated when compared with all controls (DeLorenze et al., 2006). These findings were consistent with earlier work showing that patients with MS have higher titers of CSF antibodies to EBNA1 than control subjects with other neurologic conditions, and with epidemiologic studies suggesting an association of EBV infection with MS (Tierney et al., 1994; Chen et al., 1995; Wu et al., 2002). However, as noted above and further here (Laurence and Benito-Leon, 2017), the connections between EBV infection and immune responses to EBV antigens and their roles in MS remain indistinct.

A possible link between EBV infection and autoimmunity may lie in the realms of molecular mimicry leading to "mistaken self" autoimmune attacks (Lucas et al., 2011). There have long been reports of the small chaperone/heat shock protein $\alpha$ B-crystallin (CRYAB/HSPB5) as a target for T cell responses (van Sechel et al., 1999). This protein is ordinarily not expressed in human lymphoid tissues; however, perhaps due to the stress of EBV infection, infected $B$ cells express CRYAB, along with presentation of CRYAB peptides on HLA-DR to $\mathrm{CD}^{+} \mathrm{T}$ cells, promoting an inflammatory response. Curiously, in a constructed system of antigen presentation on HLA-I molecules, the expression of CRYAB within the antigen-presenting cells did not result in $\mathrm{CD}^{+} \mathrm{T}$ cell recognition or activation (van Nierop et al., 2016). This implies a more restricted $\mathrm{T}$ cell response to CRYAB epitopes in the form of memory $\mathrm{CD} 4^{+} \mathrm{T}$ cells.

As noted above (Hecker et al., 2016), a high-density peptide array that screened MS patient sera and CSF found antibodies that reacted with EBNA1 in the domains possessing the RRPFF motif, which was also present in CRYAB. The authors suggested that antibody responses against EBV infection may lead to a breakdown of tolerance to CRYAB. As T cell help is requisite in generating effective B cell/antibody responses (Turner et al., 2017), it is conceivable that the corecognition of the RRPFF motifs from both EBNA1 and CRYAB by $B$ and $T$ cells may induce anti-EBV responses that lead to autoimmune/anti-CRYAB responses, with ensuing inflammation in the brain. The roles of CRYAB in brain inflammation are complicated (van Noort et al., 2012) and perhaps contradictory, but the extracellular presence of CRYAB from stressed astrocytes and microglia is established (Zhu et al., 2015). It is possible that potential cross-reactivity of EBNA1 antibodies to CRYAB in these scenarios may generate an autoimmune response further exacerbated by CRYAB-reactive T cells. While this discussion is obviously hypothetical, our findings over the presence of EBNA1reactive antibodies within an MS lesion (and further validation of such epitope recognition by antibodies in sera and CSF) reaffirms the potential of EBV infection and response as a factor in MS etiology and disease progression.

The approach adopted here could conceivably facilitate the identification of amino acid sequence motifs in antigens specific 
for different diseases even if the etiologies of those diseases were unknown. Notwithstanding this possibility, it is clear from several lines of evidence, including these current results, that EBV likely plays some role in MS. Whether that role proves to be causal or as a co-factor will require further investigation in the different MS phenotypes likely involving the merged environments of injury, inflammation, and immunity.

\section{Conclusion}

Using a phage peptide library, we screened $\mathrm{IgG}$ purified from a postmortem brain plaque-periplaque from an acute MS patient. These IgG bound to phage peptides representing epitopes from Epstein-Barr virus nuclear antigens 1 and 2 (EBNA1/2), The EBNA1 epitope in particular was recognized by $\mathrm{IgG}$ from MS patients while $\mathrm{IgG}$ from inflammatory control patients had significantly less binding ( $p=0.0075)$. Further, OCBs of MS patients from both sera and CSF also recognized the phage-display EBNA1 epitope. These data reaffirm the potential of EBV infection and response as a factor in MS etiology and disease progression.

Acknowledgements We thank Dr. Don Gilden for his support and guide for MS research, Dr. Greg Owens for providing purified IgG antibodies from MS brain, and Arin Graner for help with the Graphical Abstract.

Availability of Data and Materials Data are contained within the publication; otherwise, contact the corresponding author for data requests.

Contributions XY had full access to all of the data in the study and takes responsibility for the integrity of the data and the accuracy of the data analysis. ZW, PGEK, TDL, MWG, and XY contributed to the study concept and design. CD, MW, CL, TP, and XY were responsible for the acquisition of data. ZW, PGEK, TDL, MWG, and XY contributed to the analysis and interpretation of data. ZW, PGEK, MWG, and XY drafted the manuscript. CD, MW, CL, TP, and TDL provided administrative, technical, or material support. MWG and XY supervised the study. MWG and XY obtained funding. The authors read and approved the final manuscript.

Funding This work was supported by funds from the Departments of Neurology and Neurosurgery at University of Colorado Anschutz Medical Campus and by a grant from the US National Institutes of Health 1R21MH118174-01.

\section{Compliance with Ethical Standards}

Ethics Declarations Ethics approval and consent to participate

Written informed consents were obtained from all patients, and this study conformed to the principles of the Declaration of Helsinki and was approved by the MS and IC CSF samples were collected with approval from the University of Colorado Institutional Review Board (COMIRB \# 00-688).

Consent for Publication Not applicable.

Competing Interests The authors declare that they have no competing interests.

\section{References}

Afrasiabi A, Parnell GP, Fewings N, Schibeci SD, Basuki MA, Chandramohan R, Zhou Y, Taylor B, Brown DA, Swaminathan S, McKay FC, Stewart GJ, Booth DR (2019) Evidence from genome wide association studies implicates reduced control of Epstein-Barr virus infection in multiple sclerosis susceptibility. Genome Med 11: 26

Alfredsson L, Olsson T (2019) Lifestyle and environmental factors in multiple sclerosis. Cold Spring Harb Perspect Med 9

Almohmeed YH, Avenell A, Aucott L, Vickers MA (2013) Systematic review and meta-analysis of the sero-epidemiological association between Epstein Barr virus and multiple sclerosis. PLoS One 8: e61110

Alotaibi S, Kennedy J, Tellier R, Stephens D, Banwell B (2004) EpsteinBarr virus in pediatric multiple sclerosis. JAMA 291:1875-1879

Ascherio A, Munger KL, Lennette ET, Spiegelman D, Hernan MA, Olek MJ, Hankinson SE, Hunter DJ (2001) Epstein-Barr virus antibodies and risk of multiple sclerosis: a prospective study. JAMA 286: 3083-3088

Beseler C, Vollmer T, Graner M, Yu X (2017) The complex relationship between oligoclonal bands, lymphocytes in the cerebrospinal fluid, and immunoglobulin $\mathrm{G}$ antibodies in multiple sclerosis: indication of serum contribution. PLoS One 12:e0186842

Bray PF, Luka J, Bray PF, Culp KW, Schlight JP (1992) Antibodies against Epstein-Barr nuclear antigen (EBNA) in multiple sclerosis CSF, and two pentapeptide sequence identities between EBNA and myelin basic protein. Neurology 42:1798-1804

Burnard S, Lechner-Scott J, Scott RJ (2017) EBV and MS: major cause, minor contribution or red-herring? Mult Scler Relat Disord 16:24 30

Cepok S, Zhou D, Srivastava R, Nessler S, Stei S, Bussow K, Sommer N, Hemmer B (2005) Identification of Epstein-Barr virus proteins as putative targets of the immune response in multiple sclerosis. J Clin Invest 115:1352-1360

Chen F, Zou JZ, di Renzo L, Winberg G, Hu LF, Klein E, Klein G, Ernberg I (1995) A subpopulation of normal B cells latently infected with Epstein-Barr virus resembles Burkitt lymphoma cells in expressing EBNA-1 but not EBNA-2 or LMP1. J Virol 69:3752-3758

Cohen JI (2000) Epstein-Barr virus infection. N Engl J Med 343:481-492

Comabella M, Kakalacheva K, Rio J, Munz C, Montalban X, Lunemann JD (2012) EBV-specific immune responses in patients with multiple sclerosis responding to IFNbeta therapy. Mult Scler 18:605-609

Comabella M, Montalban X, Horga A, Messmer B, Kakalacheva K, Strowig T, Caballero E, Munz C, Lunemann J (2010) Antiviral immune response in patients with multiple sclerosis and healthy siblings. Mult Scler 16:355-358

Compston A, Coles A (2008) Multiple sclerosis. Lancet 372:1502-1517

DeLorenze GN, Munger KL, Lennette ET, Orentreich N, Vogelman JH, Ascherio A (2006) Epstein-Barr virus and multiple sclerosis: evidence of association from a prospective study with long-term follow-up. Arch Neurol 63:839-844

Farrell RA, Antony D, Wall GR, Clark DA, Fisniku L, Swanton J, Khaleeli Z, Schmierer K, Miller DH, Giovannoni G (2009) Humoral immune response to EBV in multiple sclerosis is associated with disease activity on MRI. Neurology 73:32-38

Ferrer M, Harrison SC (1999) Peptide ligands to human immunodeficiency virus type 1 gp120 identified from phage display libraries. J Virol 73:5795-5802

Graner M, Pointon T, Manton S, Green M, Dennison K, Davis M, Braiotta G, Craft J, Edwards T, Polonsky B, Fringuello A, Vollmer T, Yu X (2020) Oligoclonal IgG antibodies in multiple sclerosis target patient-specific peptides. PLoS One 15:e228883

Haahr S, Hollsberg P (2006) Multiple sclerosis is linked to Epstein-Barr virus infection. Rev Med Virol 16:297-310 
Hecker M, Fitzner B, Wendt M, Lorenz P, Flechtner K, Steinbeck F, Schroder I, Thiesen HJ, Zettl UK (2016) High-density peptide microarray analysis of IgG autoantibody Reactivities in serum and cerebrospinal fluid of multiple sclerosis patients. Mol Cell Proteomics 15:1360-1380

Heiskanen T, Lundkvist A, Soliymani R, Koivunen E, Vaheri A, Lankinen H (1999) Phage-displayed peptides mimicking the discontinuous neutralization sites of puumala hantavirus envelope glycoproteins. Virology 262:321-332

Hochberg D, Souza T, Catalina M, Sullivan JL, Luzuriaga K, ThorleyLawson DA (2004) Acute infection with Epstein-Barr virus targets and overwhelms the peripheral memory B-cell compartment with resting, latently infected cells. J Virol 78:5194-5204

Honarmand H, Ahmadi Jalali Moghadam M, Hatamian H, Roudbary A (2015) Possible relations between Epstein-Barr virus past infection and classic multiple sclerosis in Guilan, Iran. Jundishapur J Microbiol 8:e15985

Hutchinson M (2013) Epstein-Barr virus is a necessary causative agent in the pathogenesis of multiple sclerosis: commentary. Mult Scler 19: 1694-1695

Jespersen MC, Peters B, Nielsen M, Marcatili P (2017) BepiPred-2.0: improving sequence-based B-cell epitope prediction using conformational epitopes. Nucleic Acids Res 45:W24-W29

Kolaskar AS, Tongaonkar PC (1990) A semi-empirical method for prediction of antigenic determinants on protein antigens. FEBS Lett 276:172-174

Lamiable A, Thevenet P, Rey J, Vavrusa M, Derreumaux P, Tuffery P (2016) PEP-FOLD3: faster de novo structure prediction for linear peptides in solution and in complex. Nucleic Acids Res 44:W449W454

Laurence M, Benito-Leon J (2017) Epstein-Barr virus and multiple sclerosis: updating Pender's hypothesis. Mult Scler Relat Disord 16:814

Levin LI, Munger KL, Rubertone MV, Peck CA, Lennette ET, Spiegelman D, Ascherio A (2005) Temporal relationship between elevation of epstein-barr virus antibody titers and initial onset of neurological symptoms in multiple sclerosis. JAMA 293:24962500

Lucas RM, Hughes AM, Lay ML, Ponsonby AL, Dwyer DE, Taylor BV, Pender MP (2011) Epstein-Barr virus and multiple sclerosis. J Neurol Neurosurg Psychiatry 82:1142-1148

Lunemann JD, Kamradt T, Martin R, Munz C (2007) Epstein-barr virus: environmental trigger of multiple sclerosis? J Virol 81:6777-6784

Lunemann JD, Huppke P, Roberts S, Bruck W, Gartner J, Munz C (2008a) Broadened and elevated humoral immune response to EBNA1 in pediatric multiple sclerosis. Neurology 71:1033-1035

Lunemann JD, Edwards N, Muraro PA, Hayashi S, Cohen JI, Munz C, Martin R (2006) Increased frequency and broadened specificity of latent EBV nuclear antigen-1-specific T cells in multiple sclerosis. Brain : a journal of neurology 129:1493-1506

Lunemann JD, Jelcic I, Roberts S, Lutterotti A, Tackenberg B, Martin R, Munz C (2008b) EBNA1-specific T cells from patients with multiple sclerosis cross react with myelin antigens and co-produce IFNgamma and IL-2. J Exp Med 205:1763-1773

Lunemann JD, Tintore M, Messmer B, Strowig T, Rovira A, Perkal H, Caballero E, Munz C, Montalban X, Comabella M (2010) Elevated Epstein-Barr virus-encoded nuclear antigen-1 immune responses predict conversion to multiple sclerosis. Ann Neurol 67:159-169

Mameli G, Cossu D, Cocco E, Masala S, Frau J, Marrosu MG, Sechi LA (2014) Epstein-Barr virus and Mycobacterium avium subsp. paratuberculosis peptides are cross recognized by anti-myelin basic protein antibodies in multiple sclerosis patients. J Neuroimmunol 270:51-55

Mameli G, Madeddu G, Cossu D, Galleri G, Manetti R, Babudieri S, Mura MS, Sechi LA (2016) Immune response induced by EpsteinBarr virus and Mycobacterium avium subsp. paratuberculosis peptides in current and past infectious mononucleosis: a risk for multiple sclerosis? Eur J Neurol 23:140-147

Mechelli R, Manzari C, Policano C, Annese A, Picardi E, Umeton R, Fornasiero A, D'Erchia AM, Buscarinu MC, Agliardi C, Annibali V, Serafini B, Rosicarelli B, Romano S, Angelini DF, Ricigliano VAG, Buttari F, Battistini L, Centonze D, Guerini FR, D'Alfonso S, Pesole G, Salvetti M, Ristori G (2015) Epstein-Barr virus genetic variants are associated with multiple sclerosis. Neurology 84:1362-1368

Nielsen TR, Pedersen M, Rostgaard K, Frisch M, Hjalgrim H (2007) Correlations between Epstein-Barr virus antibody levels and risk factors for multiple sclerosis in healthy individuals. Mult Scler 13: $420-423$

Nociti V, Frisullo G, Marti A, Luigetti M, Iorio R, Patanella AK, Bianco A, Tonali PA, Grillo RL, Sabatelli M, Batocchi AP (2010) EpsteinBarr virus antibodies in serum and cerebrospinal fluid from multiple sclerosis, chronic inflammatory demyelinating polyradiculoneuropathy and amyotrophic lateral sclerosis. J Neuroimmunol 225:149-152

Owens GP, Bennett JL (2012) Trigger, pathogen, or bystander: the complex nexus linking Epstein- Barr virus and multiple sclerosis. Mult Scler 18:1204-1208

Owens GP, Burgoon MP, Devlin ME, Gilden DH (1997) Extraction and purification of active IgG from SSPE and MS brain. J Virol Methods 68:119-125

Owens GP, Shearer AJ, Yu X, Ritchie AM, Keays KM, Bennett JL, Gilden DH, Burgoon MP (2006) Screening random peptide libraries with subacute sclerosing panencephalitis brain-derived recombinant antibodies identifies multiple epitopes in the C-terminal region of the measles virus nucleocapsid protein. J Virol 80:12121-12130

Pakpoor J, Ramagopalan SV (2013) Epstein-Barr virus is a necessary causative agent in the pathogenesis of multiple sclerosis: yes. Mult Scler 19:1690-1691

Pakpoor J, Giovannoni G, Ramagopalan SV (2013) Epstein-Barr virus and multiple sclerosis: association or causation? Expert Rev Neurother 13:287-297

Pender MP, Csurhes PA, Burrows JM, Burrows SR (2017) Defective Tcell control of Epstein-Barr virus infection in multiple sclerosis. Clin Transl Immunology 6:e126

Pender MP, Csurhes PA, Lenarczyk A, Pfluger CM, Burrows SR (2009) Decreased $T$ cell reactivity to Epstein-Barr virus infected lymphoblastoid cell lines in multiple sclerosis. J Neurol Neurosurg Psychiatry 80:498-505

Ramasamy R, Mohammed F, Meier UC (2020) HLA DR2b-binding peptides from human endogenous retrovirus envelope, EpsteinBarr virus and brain proteins in the context of molecular mimicry in multiple sclerosis. Immunol Lett 217:15-24

Rand KH, Houck H, Denslow ND, Heilman KM (1998) Molecular approach to find target(s) for oligoclonal bands in multiple sclerosis. J Neurol Neurosurg Psychiatry 65:48-55

Rand KH, Houck H, Denslow ND, Heilman KM (2000) Epstein-Barr virus nuclear antigen-1 (EBNA-1) associated oligoclonal bands in patients with multiple sclerosis. J Neurol Sci 173:32-39

Ricigliano VA, Handel AE, Sandve GK, Annibali V, Ristori G, Mechelli R, Cader MZ, Salvetti M (2015) EBNA2 binds to genomic intervals associated with multiple sclerosis and overlaps with vitamin D receptor occupancy. PLoS One 10:e119605

Rowe M, Fitzsimmons L, Bell AI (2014) Epstein-Barr virus and Burkitt lymphoma. Chin J Cancer 33:609-619

Rudolf MP, Vogel M, Kricek F, Ruf C, Zurcher AW, Reuschel R, Auer M, Miescher S, Stadler BM (1998) Epitope-specific antibody response to IgE by mimotope immunization. J Immunol 160:33153321

Saha S, Raghava GP (2006) Prediction of continuous B-cell epitopes in an antigen using recurrent neural network. Proteins 65:40-48 
Salzer J, Myhr KM (2013) Epstein-Barr virus is a necessary causative agent in the pathogenesis of multiple sclerosis: no. Mult Scler 19: 1692-1693

Shannon-Lowe C, Rickinson A (2019) The global landscape of EBVassociated tumors. Front Oncol 9:713

Sundqvist E, Sundstrom P, Linden M, Hedstrom AK, Aloisi F, Hillert J, Kockum I, Alfredsson L, Olsson T (2012) Epstein-Barr virus and multiple sclerosis: interaction with HLA. Genes Immun 13:14-20

Sundstrom P, Juto P, Wadell G, Hallmans G, Svenningsson A, Nystrom L, Dillner J, Forsgren L (2004) An altered immune response to Epstein-Barr virus in multiple sclerosis: a prospective study. Neurology 62:2277-2282

Tengvall K, Huang J, Hellström C, Kammer P, Biström M, Ayoglu B, Lima Bomfim I, Stridh P, Butt J, Brenner N, Michel A, Lundberg K, Padyukov L, Lundberg IE, Svenungsson E, Ernberg I, Olafsson S, Dilthey AT, Hillert J, Alfredsson L, Sundström P, Nilsson P, Waterboer T, Olsson T, Kockum I (2019) Molecular mimicry between Anoctamin 2 and Epstein-Barr virus nuclear antigen 1 associates with multiple sclerosis risk. Proc Natl Acad Sci U S A 116: 16955-16960

Thacker EL, Mirzaei F, Ascherio A (2006) Infectious mononucleosis and risk for multiple sclerosis: a meta-analysis. Ann Neurol 59:499-503

Tierney R, Nagra J, Hutchings I, Shannon-Lowe C, Altmann M, Hammerschmidt W, Rickinson A, Bell A (2007) Epstein-Barr virus exploits BSAP/Pax5 to achieve the B-cell specificity of its growthtransforming program. J Virol 81:10092-10100

Tierney RJ, Steven N, Young LS, Rickinson AB (1994) Epstein-Barr virus latency in blood mononuclear cells: analysis of viral gene transcription during primary infection and in the carrier state. $\mathrm{J}$ Virol 68:7374-7385

Turner JS, Marthi M, Benet ZL, Grigorova I (2017) Transiently antigenprimed $\mathrm{B}$ cells return to naive-like state in absence of T-cell help. Nat Commun 8:15072

van Nierop GP, Mautner J, Mitterreiter JG, Hintzen RQ, Verjans GM (2016) Intrathecal CD8 T-cells of multiple sclerosis patients recognize lytic Epstein-Barr virus proteins. Mult Scler 22:279-291

van Noort JM, Baker D, Amor S (2012) Mechanisms in the development of multiple sclerosis lesions: reconciling autoimmune and neurodegenerative factors. CNS Neurol Disord Drug Targets 11:556-569

van Sechel AC, Bajramovic JJ, van Stipdonk MJ, Persoon-Deen C, Geutskens SB, van Noort JM (1999) EBV-induced expression and
HLA-DR-restricted presentation by human B cells of alpha Bcrystallin, a candidate autoantigen in multiple sclerosis. J Immunol 162:129-135

Warner HB, Carp RI (1981) Multiple sclerosis and Epstein-Barr virus. Lancet 2:1290

Wu H, Kapoor P, Frappier L (2002) Separation of the DNA replication, segregation, and transcriptional activation functions of Epstein-Barr nuclear antigen 1. J Virol 76:2480-2490

Yao B, Zhang L, Liang S, Zhang C (2012) SVMTriP: a method to predict antigenic epitopes using support vector machine to integrate tripeptide similarity and propensity. PLoS One 7:e45152

Yu X, Owens GP, Gilden DH (2006a) Rapid and efficient identification of epitopes/mimotopes from random peptide libraries. J Immunol Methods 316:67-74

Yu X, Burgoon MP, Shearer AJ, Gilden DH (2007) Characterization of phage peptide interaction with antibody using phage mediated immuno-PCR. J Immunol Methods 326:33-40

Yu X, Gilden DH, Ritchie AM, Burgoon MP, Keays KM, Owens GP (2006b) Specificity of recombinant antibodies generated from multiple sclerosis cerebrospinal fluid probed with a random peptide library. J Neuroimmunol 172:121-131

Yu X, Gilden D, Schambers L, Barmina O, Burgoon M, Bennett J, Owens G (2011a) Peptide reactivity between multiple sclerosis (MS) CSF IgG and recombinant antibodies generated from clonally expanded plasma cells in MS CSF. J Neuroimmunol 233:192-203

Yu X, Burgoon M, Green M, Barmina O, Dennison K, Pointon T, Davis M, Gilden D (2011b) Intrathecally synthesized IgG in multiple sclerosis cerebrospinal fluid recognizes identical epitopes over time. J Neuroimmunol 240-241:129-136

Zhang M, Davidson A (1999) A rheumatoid factor specific mimotope identified by a peptide display library. Autoimmunity 30:131-142

Zhu Z, Li R, Stricker R, Reiser G (2015) Extracellular alpha-crystallin protects astrocytes from cell death through activation of MAPK, $\mathrm{PI} 3 \mathrm{~K} /$ Akt signaling pathway and blockade of ROS release from mitochondria. Brain Res 1620:17-28

Publisher's Note Springer Nature remains neutral with regard to jurisdictional claims in published maps and institutional affiliations. 